\title{
The Networks of Consecration: The Journey of Magda Szabó and László Krasznahorkai’s International Reputation
}

One of the supposedly unquestionable verities in studies that address the reputation of contemporary Hungarian literature abroad is that they are created in two different language environments: aesthetic reputations are created by the German literary environment, while commercial success is initiated and maintained by publishing in English. Most recently, it was suggested by Adam Levy that " $[\mathrm{m}]$ any of the writers still active-Nádas, Esterházy, Krasznahorkai, Kertész and Konrád-have close ties to Germany, the region's seat of literary consecration, which has given momentum to their popular rise in English" (Levy 19). This brief description presents a rather convincing model, but does it have general applicability to all kinds of literature irrespective of genre, and does it still reflect the current state of affairs? And what contributes to the rise of reputations? Generalisations of this nature often simplify our perception of Hungarian literature's circulation, in the company of complaints that Hungarian literature is largely unknown on the international circuit, and if it is, it is simply due the emergence of new, post-200o understandings of "world literature." This chapter sets out to investigate the avenues and methods of literary consecration through the examination of the literary reputations of two very different writers: the immensely popular, widely translated and prizewinning Magda Szabó and the cultic, fêted author László Krasznahorkai. Whilst examining the methods of consecration - the award of acclaimed literary prizes and favourable reviews 
of the works in good translations published by reputed publishers-this chapter will suggest that chance encounters and carefully nurtured personal networks play an important and perceptible role in shaping the authors' presence and reputation in the international book market.

\section{Magda Szabó: The Journey of the Domestic Novelist}

Magda Szabós (1917-2007) career spanned 6o years, and she continues to be the best-known Hungarian author abroad, whose work has been more frequently translated into foreign languages than any other Hungarian writer. Her first novel, Freskó (Fresco) appeared in 1958, in the company of another novel Mondják meg Zsófikának (Tell Sally), while the third one Az öz (The Fawn) came out in 1959, and she continued to publish well into her eighties. Her three early novels were written during the cultural Stalinism of the Rákosi years, when Szabó was effectively banned from publication. During the early years of the post-1956 Kádár consolidation, her work was beginning to be classified as "tolerated," thus belonging to a middling territory between works expressly "banned" (outspokenly hostile to the communist cause), or "supported" (espousing communist ideals). Though with some unease, the nomenclature of the Kádár regime now allowed the representation of the lost world of the cultured Central European middle class, which Szabós strongly autobiographical fiction depicted. After Katalin utca (Katalin Street, 1969), Abigél (Abigail, 1970), and A szemlélök (Observers, 1973), Szabó's work was increasingly deemed to be worthy of "support"; a move that was more a reflection of the regime's changing literary preferences rather than a shift in Szabós thematic choices. Szabó herself, although never denying her Western outlook and essentially bourgeois values, made sure that she maintained amicable ties with the cultural nomenclature of the regime, thusin a bid to guarantee her own participation and success in the state socialist world of publishing - undertaking the role of the "adjusting [or adapting] writer" (Kiss 25). The success of this complex manoeuvring is best shown by the events of 1977-78: in 1977, she published the multigenerational family novel Régimódi történet (Old-Fashioned Story), which monumentalised the late nineteenth early twentieth cultured provincial middle class, and in 1978, she was awarded the most prominent Hungarian state award, the Kossuth Prize, for her lifetime achievement (Osztovits). In the eighties, she was already largely written off as dated and repetitive, when, in 1987, she unexpectedly published Az ajtó (The Door), whose success proved that readers were still hungry for psychologically motivated realistic novels. At the age of 85 , she published her final family novel under the title Für Elise (2002) (Osztovits). For her most appreciative critics, the two earliest 
novels, An Old-Fashioned Story, and her late fiction The Door and A pillanat (The Moment) count as the best of her oeuvre (Kabdebó).

The travels of Szabós work started with the publication of her novels in Germany, in which her personal connections played a significant role. Her entry was tinged with a degree of political subversion, if not radicalism. Fresco, already translated into German by the noted translator Mirza von Schüching (1896-1967), who lived in Budapest and was married to the prominent translator Géza Engl (1894-1988), was smuggled out of Kádár's Hungary for the attention of the Nobel Prize winning German author Hermann Hesse (Morgenstern). Hesse knew nothing about Szabó but he knew Schüching, and wasted no time alerting his publisher the Fischer Verlag to the value of his new discovery of the unknown novelist. As he put it, "I have caught a goldfish for you, don't let it escape." (Rérolle) Schüching’s translation (1960) paved the way for Szabós German reception and several of Szabós works came out in German in quick succession: Das Fresko (The Fresco) in 1960 by the Württemberg-based Insel Verlag (10 editions between 1960 and 1964), Die Danaida (A danaida) (6 editions between 1963 and 1965) Die andere Ester ( $A z$ öz, 5 editions between 1961 and 1963) and others. The balancing act behind Szabós presence in the German language area was similar to the manoeuvres described above: her work was actively championed abroad by the Hungarian government's Copyright Protection Office (Szerzői Jogvédő Hivatal, 1953-1996, also known as Artisjus), whose remit covered promoting the international career of favoured Hungarian writers, but it was also the beneficiary of the patronage offered by the émigré Swiss-Hungarian literary critic and translator Éva Haldimann, with whom she started a correspondence in 1970 (Kiss 26). Haldimann, through her reviews in the Neue Zürcher Zeitung, set the tone for the responses to the Hungarian work: in 1977, she had already reported about Imre Kertész, and she had also translated Katalin Street into German (1971). She reviewed each of Szabós works in the periodical, and the story of the affectionate ties between the two women is is now available in the volume Drága Kumacs! (Kiss 26). In the late 1980s, Henning Paetzke continued the Schüchings' work by rendering An Old-Fashioned Story (Eine altmodische Geschichte, 1987) and The Door (Hinter der Tür, 1992, 2010) into German. Though Szabó received no prestigious literary prizes in Germany, the continued translation of her oeuvre, the regular reviews in the Frankfurter Allgemeine Zeitung and in the Neue Zürcher Zeitung, and the frequent republishing of her work under West German market conditions suggests an unbroken popularity with the readers.

In contrast with the German journey, the early French reception of her work followed a model rather characteristic of the general export of Hungar- 
ian letters: the earliest translations were supplied by Hungarian émigré literati, often with the assistance of a target language native speaker. Ladislas Gara (Le faon/The Fawn, 1962) and Georges Kassai (Fresque/Fresco, 1963) provided decent translations for the Parisian Éditions Seuil, a highly regarded house with a reputation for publishing radical works of the "literature of commitment" such as Franz Fanon's Black Skin, White Masks (1952), but also bringing out foreign work yet to become global classics such as Günther Grass's Tin Drum (1959) and Ingeborg Bachmann's La trentiene année (1963). Szabóss work fell under the latter category, though there is no obvious trace of any reception in the 1960s. The critical indifference was continued after the regime change in 1989 when her realist fiction seemed too dated and traditional for the suddenly curious Western reader, expecting aesthetic innovation or political subversion in beyond Iron-Curtain literature.

The efforts of a tireless émigré academic played an important role in grounding Szabós's work in the French literary world, when the French-born Germanist Chantal Philippe picked up the torch in the 1990s. Attracted to Hungarian for its sonorous sounds and intriguing grammar, Philippe began to study with the Hungarian-born professor of linguistics Tamás Szende at the Parisian INALCo (Institut National des Langues et Civilisations Orientales), who encouraged her to try her hand at translating László Németh's short novel Gyász (Mourning). She came to translating Szabós The Door (La porte) out of personal interest, but Éditions Seuil rejected her submission. The text lay in her drawer for several years until the moment when Viviane Hamy, a publisher with an established history of introducing Frigyes Karinthy's and Dezső Kosztolányi's work in the early 1990s, approached her with a tentative enquiry about working on Szabó. To Hamy's surprise, the translation was already complete, and this coincidence cemented their relationship and also marked out Chantal Philippe as the chief translator of Szabó into French (Grebot).

The award of the prestigious French "Prix Femina Étranger" for The Door in 2003 only affirmed Hamy's faith in Szabós exceptional qualities (Balassi). The prize, which is awarded by an exclusively female jury to male or female foreign writers of fiction, was not only the first international prize awarded to Szabó, but Szabó's work is the only Hungarian book to receive this honour to date. In 2007, Philippe's translation of another Szabó novel Katalin Street was awarded the "Prix Cévennes" for the best European novel published in that year in French translation, honoured for its outstanding contribution to the cultural diversity of Europe.

Szabós reputation in the English-speaking world started with her work being noticed in international journals of book reviews, which was, just as in the case 
of Gara and Kassai, the labour of love for mid-twentieth century Hungarian émigrés, searching for the treasures of Hungarian literature. Her work was occasionally mentioned in Books Abroad (1927-1977) and its successor World Literature Today (1977-2019), where George Gömöri and Clara Györgyey conscientiously reported on works yet untranslated. These reports are framed by theme and politics: Gömöri praises Mózes 1, 22 (Gömöri 1967: 294-295) for reflecting on generational conflict and reporting on social malaise; Old-Fashioned Story (Gömöri 1978: 499) is praised for its sharp-eyed realism in the dissection of family drama. Györgyey, in 2003, commends the strongly autobiographical Für Elise for its psychological realism (Györgyey 103-104). This recognition, though doing little to increase readership directly, contributed much to the general awareness of Hungarian fiction's existence and merits.

The Anglophone publishing scene was similar to the French in the sense that it showed interest in translations only after the 1989 political changes. Earlier publications went practically unnoticed, no matter whether they were published by the Budapest-based Corvina Publishing House, tasked with publishing Hungarian work in foreign languages by state socialist cultural authorities, or by international publishers such Cape of London. The first full work to be brought out after 1989 was Stefan Draughon's translation of The Door (1995), followed by Agnes Farkas Smith's rendering of Katalin Street (2008), while the prize-winning versatile translator and poet George Szirtes contributed Iza's Ballad (Pilátus, 2012). It was the Rhodesian-born, England-based Len Rix's passionate commitment to translating Szabó's work into English that secured its critical reputation in the English-speaking world. In 2006, his version of The Door (2005), published by the Harvill Secker Press, was awarded the Oxford Weidenfeld Translation Prize, which also paved the way for the New York Times Best Book Prize in 2015. Rix's translation of Katalin Street was awarded the PEN Translation Prize in 2018, and his translation of Abigail is due to be published by Penguin in 2020. An analysis of the film version of The Door 2012 (dir. István Szabó) and the public appeal of such a transmedial reworking is beyond my scope in the present, but suffice to say that the very existence of the film-the international cooperation led by the Oscar-winning Hungarian director, starring the Oscar winning Helen Mirren-attests to the prestigious status of Szabós fiction in Britain.

Literary reportage and analysis are often devoted to translated works only when these books attain a headline-worthy award, but the reviews of Szabós work largely reacted to the publication of Rix's translations, and some early reviews focus on the incorporation of East Central European history into a domestic drama (Kurdi 94-95). Already in 2005, Liam McIlvanney's long review in The London Review of Books suggested that The Door was "a superbly con- 
trolled and involving work of art... One of Szabós triumphs is to have written a profound political novel that is rooted in the domestic.... Ultimately, the text is a tranquil memento, a piece of irrefutable poetry, a bizarre counterpart to our universal betrayal-out of love" (McIlvanney 7-8). Reviews, appearing in great numbers after the reissue of Rix's text by New York Books Classics in 2016, captured the thematic dimension and the psychological dynamics of the novel: this dark domestic tale is "subtle, intellectual, and if not exactly unflinching then certainly told with bone-scraping honesty" (Temple). Deborah Eisenberg's refers to the "white-knuckled experience" when describing the effects of the book's psychological precision (Eisenberg). Other reviews go beyond the domestic dimension of the novel, and point at the underlying mythological narrative of "Fates" in the story (Messud), while Cynthia Zarin sees a "parable" in the book, understanding its conflict not in terms of psychology, but as a human infringement upon the moral order set by the (Greek) gods (Zarin).

Indeed, Szabó frequently expressed her surprise about her international reputation, as she saw her work as firmly embedded in Hungarian past and presence. But these perceptive reviews suggest that the local/political and the universal are dialectical (rather than dichotomous) categories, and the ostensibly domestic plotline is just the most apparent layer of fiction whose use of the universals does have a significant appeal to the global audience.

\section{László Krasznahorkai: The Journey of the Cult Writer}

While the Calvinist Presbyter Szabó used the patterns of Greek mythology to understand human action, the universe of László Krasznahorkai has been interpreted by eschatological categories such as apocalypse, doom and revelation ever since its appearance. The author of puzzling, postmodern fiction of a dystopian human condition is separated from Szabó not only by an entirely different aesthetic but also by a generation; a difference that shapes and structures his relationship to the processes of mediation in reaching international audiences. Krasznahorkai, born in 1954 and bursting into the high-intensity Hungarian literary scene in 1985, published Sátántangó (Satantango, 1985), Kegyelmi viszonyok (Relations of Grace, short stories, 1986) and Ellenállás melancholiája (Melancholy of Resistance, 1989) in quick succession. He quickly established the reputation as a writer of fiction that is intellectually stimulating and intensively demanding, but also immensely depressing for its depiction of a world beyond salvation, and his cult-like status began to form in the mid-1980s.

The international circulation of Krasznahorkai's work was started off by the award of the German Academic Exchange (DAAD) Berlin Writer Fellowship 
in 1987. Introduced in a bid to break down the intellectual isolation of West Berlin, these fellowships were designed to attract an international body of authors, but it was only Poland and Hungary in the communist bloc that allowed their citizens to participate (Dalos). By the mid-198os, several Hungarian contributors to samizdats or authors associated with the emerging democratic opposition were the recipients of the fellowship. Krasznahorkai's stay in West Berlin resulted in Hans Skirecki's brave attempt at translating Relations of grace/ Gnadenverhältnisse in 1988. With the sudden and fast collapse of communism, apocalyptic and trauma narratives from East Central Europe suddenly met with an avid interest, and Krasznahorkai, aided by Skirecki's dedication to rendering his oeuvre into German, became firmly established in the German literary scene. Satantango came out in 1990, and after the 1992 publication of Melancholy of Resistance/Melancholie des Widerstands, the latter volume was awarded the Best Book of the Year award (Bestenliste-Preis, 1993). Perhaps inevitably, critics were initially inclined to read political allegories into the works, though most reviews were much more universal in scope (Zsadányi 210). After Skirecki's death, his work was continued by the Swiss-Hungarian Christina Viragh, providing a flow of translations in German. Reception and response to Krasznahorkai's work is thus continued by the next generation of translators. Satantango has also had an almost separate life as an arthouse "slow film" based on the novel directed by the Hungarian director Béla Tarr (1994), with a circulation in a very specific segment of the international market, making Krasznahorkai's name internationally known before his books were translated (IMDB).

A very deliberate and planned effort on the émigré scholar Tamás Szende's part led to the translation of Krasznahorkai's work into French, after Szende encouraged his student Joëlle Dufeuilly to explore Krasznahorkai's work. Dufeuilly was still a "traductrice débutante" when she approached a number of publishers with her finished Tango de Satan by the writer unknown in France. She was rather surprised to be accepted by Gallimard (Grelle). We can only speculate about the editors' familiarity with the German or English presence of the novel, or the effect of the arthouse movie. In any case, Gallimard brought out Satantango in 2000, followed by another six titles. A self-reflexive writer, Dufeuilly stresses, "the immense responsibility of the translator ... especially when it comes to French, which is the second most commonly used target language of translation. Many authors would never be read if they were not translated into French." Her working relationship with Krasznahorkai, which she describes as that of an "old couple," resulted in the appearance of all his major novels and attracted several major translation prizes, including the "Grand Prix de la Société des gens de lettres" for Guerre et guerre in 2014 (Dufeully). 
Similarly to the presence of Szabó and other Hungarian writers, World Literature Today was immensely useful in familiarising the Anglophone reader with Krasznahorkai's name. When George Gömöri commented on the recently published and yet untranslated Satantango in 1986, he already called Krasznahorkai a "talent to watch" and praised his work for its psychopathological characters, the post-avant-garde Kafkaesque world, and the instability of an interpretive mode, by which he meant that the novel is "too concrete for a parable and too abstract for a critically observed slice" (Gömöri 1986: 341). Though the connection between these reviews and later market presence is rather tenuous, short reviews of this nature should be acknowledged for keeping the international world aware of the existence of literature still behind the Iron Curtain.

Krasznahorkai's unchallenged international status is inextricably linked to George Szirtes's versatile and established rendering of his work into English. It was Krasznahorkai himself who requested hiring Szirtes to translate The Melancholy of Resistance, Krasznahorkai's first novel in English, which eventually came out ten years after the German translation (1998). The Melancholy of Resistance has enjoyed another four editions in London and New York, followed by War and War in 2006 and, in 2012, Satantango, the novel most commonly associated with Krasznahorkai's name, also appeared after a long gestation period (Krasznahorkai). It was on Szirtes's recommendation that Ottilie Mulzet was commissioned to translate Seiobo there below (2013). Szirtes's assessment of Mulzet's abilities proved correct when his own Satantango (2013) and Mulzet's Seiobo (2014) won the University of Rochester's Three Percent Best Translated Book Award (University of Rochester). Thus, Krasznahorkai's work was awarded this prize two years in a row. The Man Booker International Prize in 2015 was thus based on four existing titles in English, and it rewarded one author's "continued creativity, development and overall contribution to fiction on the world stage," rather than one particular title. Though not a translation prize per se, the nature of the prize is that it is shared by the author and his two translators, George Szirtes and Ottilie Mulzet (Flood).

In the early reviews, references to the associations with Kafka, Faulkner, Dostoyevsky dominate, accompanied by the description of obvious formal elements; George Szirtes refers to his prose as "a slow lava-flow of narrative, a vast black river of type," and the terms like "visionary," "manic" and "obsessive" frequently appear. A more incisive analysis in term of postmodernism did not come until around 2012, when Anglophone critics began their systematic interrogations. Jacob Silverman, in a long essay, suggests that in Krasznahorkai's work, the attainability of knowledge is questioned as allegories promising interpretation are demolished, and "[i]t is often hard to know exactly what 
Krasznahorkai's characters are thinking, because his fictional world teeters on the edge of a revelation that never quite comes." Krasznahorkai returns to this idea in The Melancholy of Resistance, where he speaks of "the realization that knowledge led either to wholesale illusion or to irrational depression" (Silverman). Auerbach, trained in postmodernist theory, in a similar tone suggests that Krasznahorkai's major concern is the process of making meaning in a world where psychology and rationality are no longer serviceable tools of interpretation. The abundance of incisive reviews suggests that critics, now able to consult much of Krasznahorkai's work in high quality translation, are able to begin building a critical vocabulary to address the work. While aspiring to a mass readership would be futile, this notoriously difficult writer now has a faithful cult of followers.

\section{Conclusions}

Having surveyed the international careers of two of the very small group of Hungarian writers of fiction to be noted on the international circuit, the critic is left with some important and perhaps unexpected conclusions. It is indeed notable that the loosely understood term "international circulation" still depends on the judgement "French, German or English-speaking arbiters of literary taste" (Chitnis 3) and currently we have no significant knowledge of the processes of at work in popularising Hungarian literature in other large reader groups (e.g. Russian, Spanish or Chinese), nor do we know much about those informal channels between the different editorial houses in charge of commissioning translations. But the dichotomy between the "aesthetic" and the "popular" success (and the "momentum" the former gives to the latter) could be given a more nuanced understanding if "stages of circulation" stood in the focus. In this process, Germany plays a particularly important role as the entry point-the first language area with an international publishing industry-to a work's international journey, and this role applies even when critics are not raving and prizes are not forthcoming. Indeed, both Szabó and Krasznahorkai received more prestigious prizes elsewhere; hence, prize-based consecration is not directly associated with Germany. Presence in the French-language textual universe and the award of French prizes should, on the other hand, be more vocally acknowledged: as Szabó's example illustrates, gender, genre, and a sense of building a European collective textual self are highly prized and passionately sought qualities amongst French critics. British publications play a third type of important role in the reception of these texts, partly for the transatlantic publishing potential. Literary consecration, therefore, is not specifically re- 
lated to favourable reviews or prestigious prizes, but can easily be understood as the complex work of transmitting information and influences between important actors in the international language arenas in conjunction with the writers and other Hungarian agents. The influence and impact of adapting fiction to the screen-which happened both in the case of Szabó and Krasznahorkai, and which arguably contributed significantly to the circulation of their names-and cinematic impact on sales figures of the texts should be pursued in a separate study.

But what is not to be forgotten in the discussions of these influences is the human agency behind enabling, creating, and reproducing these influences. The role of the literati from the Hungarian language community (frequently, though not necessarily émigré) appears to play an indispensable and hitherto unacknowledged role in literary transmission. These manifold roles-reporting in trade journals, training translators or encouraging the wider acknowledgement of Hungarian writing in translation-have shown to be indispensable for establishing the reputation of Hungarian work abroad.

\section{| References}

\section{PRIMARY SOURCES}

Krasznahorkai's works in Hungarian

Krasznahorkai, László. Sátántangó. Budapest: Magvető, 1985.

---. Kegyelmi viszonyok. Budapest: Magvető, 1986.

---. Az ellenállás melankóliája. Budapest: Magvető, 1989.

---. Háború és háború. Budapest: Magvető, 1999.

---. Báró Wenckheim hazatér. Budapest: Magvető, 2017.

Krasznahorkai's works in German

Krasznahorkai, László. Gnadenverhältnisse. Trans. Hans Skirecki and Juliane

Brandt. Berlin: Literarisches Colloquium Berlin, 1988.

---. Satanstango. Trans. Hans Skirecki. Reinbek bei Hamburg, 1990.

---. Melancholie des Widerstands. Trans. Hans Skirecki. Zürich: Ammann, 1992.

---. Im Norden ein Berg, im Süden ein See, im Westen Wege, im Osten ein Fluss.

Berlin: Fischer, 2005.

---. Baron Wenckheims Rückkehr. Berlin: Fischer, 2018. 
Krasznahorkai's works English translations

Krasznahorkai, László. Melancholy of Resistance. Trans. George Szirtes. London:

Quarter Books, 1998.

---. War and War. Trans. George Szirtes. London: New Directions, 2006.

---. Satantango. Trans. George Szirtes. New York: New Directions, 2012.

Krasznahorkai's works French translations

Krasznahorkai, László. La mélancolie de résistance. Trans. Joëlle Dufeuilly. Paris:

Gallimard, 2006.

---. Guerre et guerre. Trans. by Joëlle Dufeuilly. Arles: Actes Sud, 2015.

---. Tango de Satan. Trans. Joëlle Dufeuilly. Paris: Gallimard, 2017.

Szabós works in Hungarian

Szabó, Magda. Freskó. Budapest: Magvető, 1958a.

---. Mondják meg Zsófikának. Budapest: Budapest Magvető, 1958b.

---. Az őz. Budapest: Szépirodalmi, 1959.

---. A danaida. Budapest: Szépirodalmi, 1964.

---. Mózes 1, 22. Budapest: Magvető, 1967.

---. Katalin utca. Budapest: Szépirodalmi, 1969.

---. Abigél. Budapest: Móra, 1970.

---. A szemlélők. Budapest: Magvető, 1973.

---. Régimódi történet. Budapest: Szépirodalmi, 1977.

---. Az ajtó. Budapest: Európa, 1987.

---. A pillanat. Budapest: Magvető, 1990.

---. Für Elise. Budapest: Európa, 2002.

Szabó's works in English translation

Szabó, Magda. The Fawn. Trans. Kathleen Szasz. London: Cape 1963 .

---. Tell Sally. Trans. Ursula McLean. Budapest: Corvina, 1963b.

---. An Old-Fashioned Story. Trans. Boris Jancsó. Budapest: Centre Hongrois, 1978.

---. The Door. Trans. Stefan Draughon. Boulder: East European Monographs, 1995.

---. The Door. Trans. Len Rix. London: Harvill-Secker, 2005.

---. Katalin Street. Trans. Agnes Farkas Smith. Kids 4 kids Press, 2008.

---. Iza's Ballad. Trans. George Szirtes. London: Harvill-Secker, 2014.

---. Katalin Street. Trans. Len Rix. London: Penguin, 2017.

Szabós works in German translation

Szabó, Magda. Das Fresko. Trans. Mirza Schüching. Wiesbaden: Insel, 1960.

---. Das andere Esther. Trans. Mirza Schüching. Frankfurt-am-Main: Insel, 1961.

---. Die Danaida. Trans. Mirza Schüching. Frankfurt-am-Main: Insel, 1965. 
---. Eine altmodische Geschichte. Trans. Henning Paetzke. Berlin: Volk und Welt, 1987.

---. Hinter der Tür. Trans. Henning Paetzke. Frankfurt-am-Main: Insel, 1992.

Szabó's works in French translation

Szabó, Magda. Fresque. Trans. Georges Kassai, adapted by Roger Richard. Paris: Seuil, 1963.

---. Le faon. Trans. Monique Fougerousse and Ladislas Gara. Paris: Seuil, 1962.

---. La porte. Trans. Chantal Philippe. Paris: Hamy, 2003.

---. Rue Katalin. Trans. Chantal Philippe. Paris: Hamy, 2006.

Secondary sources

Auerbach, David. “The Mythology of Laszlo Krasznahorkai.” Quarterlyconversation, https://tinyurl.com/yxax4xr7. Accessed 7 June 2010.

Balassi Institute, Paris. “Soirée litteraire Autour Magda Szabó,” https://tinyurl. com/y4wouuoo. Accessed 12 December 2017.

Burger, Anikó. “Szabó Magda világsikere,” https://tinyurl.com/y6p5nzpa. Accessed 12 December 2017.

Chitnis, Rajendra. "Translating the Literatures of Smaller European Nations: A Picture from the uK, 2014-2016," https://tinyurl.com/yc9algl7. Accessed 12 December 2017.

Dalos, György. Email communication via József Havasréti, 6 September 2019.

Dufeully, Joëlle. "Recontre avec Joëlle Dufeuilly," https://tinyurl.com/y4wabg7o. Accessed 11 November 2014.

Eisenberg, Deborah. "A blinding need for each other. The Door by Magda Szabó." New York Review of Books, https://tinyurl.com/y683nc3p. Accessed 7 April 2016.

Flood, Alison. “Man Booker International Prize 2015 won by 'visionary’ László Krasznahorkai." The Guardian, https://tinyurl.com/leumz23. Accessed 15 May 2015.

Gömöri, George. “Mózes egy, huszonkettő.” Books Abroad 43. 2. (1969): 294-295.

Gömöri, George. “'Sátántangó by László Krasznahorkai.” World Literature Today 60.2 (1986): 340-341.

Gömöri, George. “'Régimódi történet' by Magda Szabó.” World Literature Today 52.3 (1978): 499.

Grebot, Agnes. "PRIX Nicole Bagarry-Karatson 2004: Chantal Philippe."

https://tinyurl.com/y6hptmmn. Accessed 15 May 2015.

Grelle, Martine and Floriane Laurichesse. “Traduire László Krasznahorkai: entretien avec Joëlle Dufeuilly." Balises: Le magazine de la Bpi.

https://tinyurl.com/y4u6gdob. Accessed 4 April 2018. 
Györgyey, Clara. “Für Elise by Magda Szabó.” World Literature Today 77. 3.4 (2003): 103-104.

Satantango, https://tinyurl.com/y36ltd35. Accessed 4 May 2020.

Kabdebó, Loránt. “Szabó Magda, az iró és irodalomtörténész.' Irodalomtörténet 3 (1977).

https://tinyurl.com/y9jtkuf6. Accessed 4 April 2018.

Kiss, Noémi. "Nem tudom, mit kezdjek magammal." Szabó Magda száz éve. Budapest: Orpheusz, 2019. 24-29

Krasznahorkai, László. "My hero: Geoge Szirtes and my other Translators." The Guardian, https://tinyurl.com/ombau85. Accesssed 23 May 2015.

Kurdi, Mária. "Az ajtó fogadtatása az angol nyelvü országokban.” Szabó Magda száz éve. Budapest: Orpheusz, 2019. 9-104.

Levy, Adam. “The Immediacy of Influence.” World Literature Today Jan-Feb (2013): 18-19.

McIlvanney, Liam. “That Time.” London Review of Books, 27.24. (2005): 7-8.

Messud, Claire. “The Door by Magda Szabó.” New York Times, https://tinyurl. com/laolkz4. Accessed 6 February 2015.

Morgenstern, Ulf. Bürgergeist und Familiensinn: Die liberale Gelehrtenfamilie Schüching im 19. Und im 19. und 20. Jahrhundert. Paderborn: Schöningh, 2012.

Osztovits, Ágnes. “A Szabó Magda talány.” Válasz, https://tinyurl.com/y6eqouyb. Accessed 28 June 2017.

Rérolle, Raphaelle. "Magda Szabo, romancière hongroise." Le Monde, https://tinyurl.com/y9vavncc. Accessed 22 November 2007

Silverman, Jacob. “The devil they know: Laszlo Krasznahorkai's 'Satantango.” New York Times, https://tinyurl.com/ybnep5f3. Accessed 16 March 2012.

Szabó, Magda. Drága Kumacs! levelek Haldimann Évának. Budapest: Európa, 2010.

Tempe, Emily in Flavorwire quoted in: https://tinyurl.com/y3j4y858. Accessed 4 April 2018.

Zarin, Cynthia. “The Hungarian Despair of Magda Szabós The Door." The New Yorker, https://tinyurl.com/gufxfjs. Accessed 19 April 2016.

FILMOGRAPHY

Satantango. Dir. Béla Tarr, 1994.

The Door. Dir. István Szabó, 2012. 


\section{| Abstrakt}

ZsUZSANNA VARGA

Sieci święcenia - droga Magdy Szabó i László Krasznahorkaiego do międzynarodowej popularności

Artykuł porusza temat międzynarodowej popularności dwojga węgierskich powieściopisarzy końca xx i początku xxI w., recepcji powieści Magdy Szabó i László Kraszahorkaiego w niemieckim, francuskim i angielskim kręgu literackim. Pomimo że są to autorzy różniący się podejściem do samego gatunku i estetyki powieści, należą oni do niewielkiej grupy pisarzy, których twórczość wzbudziła zainteresowanie za granicami ich ojczyzny. Artykuł dowodzi, że zaistnienie tych autorów na polu międzynarodowym, recepcja i popularność są wyraźnie związane z intensywną działalnością tłumaczy i innych pośredników kulturowych, działających na międzynarodowym rynku literatury.

Słowa kluczowe: Magda Szabó; László Krasznahorkai; literatura węgierska; popularność międzynarodowa

\section{| Abstract}

ZsUZSANNA VARGA

The Networks of Consecration: The Journey of Magda Szabó and László Krasznahorkai's International Reputation

This chapter focuses on the international reputation of the work of two Hungarian novelists the late twentieth and early twenty-first centuries: the reception of the novels of Magda Szabó and László Kraszahorkai in German, French and English literary cultures. Though different in novelistic approach, genre and aesthetics, they belong to a small group of Hungarian writers whose work found resonance with the international readership. The chapter argues that their international circulation, reception and popularity are much entwined with very tangible processes of mediation through networks of translators and other cultural agents active in the international economy of letters.

Keywords: Magda Szabó; László Krasznahorkai; Hungarian literature; international reputation 


\section{| About the Author}

Zsuzsanna Varga studied English, Hungarian and Portuguese at Eötvös Loránd University, Budapest. She took her PhD in Victorian English literature at the University of Edinburgh. Since 2008, she has taught Hungarian Studies at the University of Glasgow. Her research interests include reception studies, travel writing and digital humanities. Her publications include Worlds of Hungarian Writing (Fairleigh Dickinson, 2016, co-edited), Popular Cinemas in East Central Europe (Ів Tauris, 2017, co-edited), and Reflections in the library: Antal Szerb's selected literary essays 1926-1944 (Legenda-MHRA, 2017).

E-mail: zsuzsanna.varga@glasgow.ac.uk 
